\title{
Participation in Leisure Activities and Social Integration of Migrant Workers Xiaobing Huang ${ }^{1}$, Xiaolian Liu ${ }^{2, \text { a, * }}$ \\ ${ }^{1}$ School of Business, Gannan Normal University, Ganzhou 341000, China; ${ }^{2}$ School of History and Tourism, Gannan Normal University, Ganzhou 341000, China *, a Liu Xiaolian@163.com
}

Keywords: Leisure Activities; Group Heterogeneity; Migrant Workers; Social Integration.

\begin{abstract}
This paper analyzes the situation and impact of participation of leisure activities on social integration of migrant workers from group heterogeneity perspective. The study indicates that participation of leisure activities can promote social integration of migrant workers significantly. Moreover, Social-type and arty-type leisure activities can aggrandize social integration of migrant workers, the effect of sporty-type leisure activities isn't notable, but, recreational leisure activities will undermine social integration.
\end{abstract}

\section{Introduction}

Since the reform and opening up, a large number of rural labor forces have chosen to leave the countryside to work in the city, forming a special social group of "migrant workers". According to the statistics released by the national bureau of statistics, the total number of migrant workers in China totaled 2.817 million in 2016, an increase of 4.24 million over the previous year, an increase of 1.5 percent. The realization of integration into the city is the major issue facing China's urbanization process.

Some studies abroad have shown that leisure activities can improve the subjective well-being of individuals (Berger et al., 1988). For China's migrant workers, however, due to long time and high strength work, the role of rural traditional concept and social distance, the motivation of migrant workers in cities to participate in leisure activities and the frequency is not high.

In this background, this paper studies the status of migrant workers' social integration and the relationship between leisure activity participation and social integration using a survey data and puts forward some targeted policy recommendations.

\section{Measure}

We utilize a five-response questionnaire conforming to the Likert scale with reference to the literature on measures of social integration. The survey was conducted by the School of Business of Gannan Normal University from May to August 2013 in the Jiangxi province, Guangdong province, Henan province and Helongiiang province with face-to-face interviews. The predetermined sample size is 1000 , we finally acquire survey data with 869 effective samples after excluding 131 ineligible correspondents.

We propose an indicator consisting of five components to measure the social integration of Chinese migrant workers including social distance, cultural integration, psychological integration, social interaction and settlement.

We employ an exploratory factor analysis method using principal-component analysis and Varimax with Kaiser Normalization. The "eigenvalue greater than 1" criterion is adopted to determine the number of factors to extract. The factor analysis is implemented in SPSS, Version 18.0. SPSS reports a Kaiser-Meyer-Olkin (KMO) index of 0.726 and an associated Barlett chi-square test which is significant at the $1 \%$ level $(\mathrm{P}<0.001)$, thereby indicating that the correlation matrix was factorable. The scree test yields a solution for all five factors with eigenvalue greater than 1 . This five-factor solution accounts for $62.458 \%$ of the variance in the factor matrix. 
The factor analysis in Table 1 shows that the four items we designate to measure the social distance have high loadings ranging from 0.709 to 0.814 , indicating that these four items can explain and define social integration well. Analogously, we observe that the items we choose for other aspects of social integration enjoy high loadings. As a consequence, we could perfectly combine all of the 16 items into 5 common factors and use them to measure the social integration of Chinese migrant workers.

Table 1 . The results of factor analysis

\begin{tabular}{|c|c|c|c|c|c|c|}
\hline & Variable & $\begin{array}{c}\mathrm{F} 1 \\
(2.29895)\end{array}$ & $\begin{array}{c}\mathrm{F} 2 \\
(1.55486)\end{array}$ & $\begin{array}{c}\text { F3 } \\
(1.44442)\end{array}$ & $\begin{array}{c}\mathrm{F} 4 \\
(1.22029)\end{array}$ & $\begin{array}{c}\text { F5 } \\
(1.03679)\end{array}$ \\
\hline \multirow{4}{*}{$\begin{array}{l}\text { Social } \\
\text { distance }\end{array}$} & $\begin{array}{l}\text { Local residents discriminate } \\
\text { against us }\end{array}$ & .814 & -.068 & .042 & -.053 & -.059 \\
\hline & I don't belong in the city & .805 & .070 & .014 & -.042 & -.015 \\
\hline & I feel like a stranger & .742 & -.062 & .016 & -.108 & -.008 \\
\hline & $\begin{array}{c}\text { It is difficult to get along with } \\
\text { residents }\end{array}$ & .709 & .016 & .013 & .024 & -.029 \\
\hline \multirow{3}{*}{$\begin{array}{l}\text { Cultural } \\
\text { integration }\end{array}$} & $\begin{array}{c}\text { It is important to behave } \\
\text { according to hometown norms }\end{array}$ & -.041 & .866 & .052 & .155 & .124 \\
\hline & $\begin{array}{c}\text { It is important to keep the } \\
\text { hometown lifestyle }\end{array}$ & .083 & .819 & .169 & .031 & .074 \\
\hline & \begin{tabular}{|c|}
$\begin{array}{c}\text { It is important to obey } \\
\text { hometown customs }\end{array}$ \\
\end{tabular} & -.081 & .789 & .031 & .106 & .137 \\
\hline \multirow{4}{*}{$\begin{array}{l}\text { Psychological } \\
\text { integration }\end{array}$} & $\begin{array}{c}\text { Your children should speak the } \\
\text { hometown dialect }\end{array}$ & .021 & .092 & .811 & -.064 & .033 \\
\hline & $\begin{array}{c}\text { I feel like I am a member of the } \\
\text { local city }\end{array}$ & .088 & .057 & .752 & .110 & -.003 \\
\hline & I consider myself a city dweller & -.072 & .014 & .740 & -.076 & .110 \\
\hline & I think I belong to the local city & .057 & .103 & .549 & .292 & .034 \\
\hline \multirow{3}{*}{$\begin{array}{c}\text { Social } \\
\text { interaction }\end{array}$} & I can speak the local dialect & -.107 & .092 & .004 & .775 & .128 \\
\hline & $\begin{array}{c}\text { I am familiar with local } \\
\text { customs }\end{array}$ & .043 & .128 & .122 & .719 & -.008 \\
\hline & $\begin{array}{l}\text { I have frequent contact with } \\
\text { city dwellers }\end{array}$ & -.152 & .039 & .001 & .561 & .331 \\
\hline \multirow[t]{2}{*}{ Settlement } & $\begin{array}{c}\text { I want buy an apartment in the } \\
\text { city }\end{array}$ & -.046 & .109 & .079 & .160 & .859 \\
\hline & $\begin{array}{c}\text { I want to settle down and } \\
\text { develop a career in the city }\end{array}$ & -.025 & .212 & .083 & .127 & .838 \\
\hline \multicolumn{2}{|r|}{ Proportion } & 20.641 & 15.733 & 10.871 & 8.571 & 6.641 \\
\hline \multicolumn{2}{|r|}{ Cumulative } & 20.641 & 36.374 & 47.245 & 55.817 & 62.458 \\
\hline \multicolumn{2}{|r|}{ Cronbach $\alpha$} & .774 & .704 & .799 & .565 & .736 \\
\hline
\end{tabular}

Note: Extraction Method: Principal Component Analysis. Rotation Method: Varimax with Kaiser Normalization. The eigenvalues are reported in the parentheses. 


\section{Results}

In order to analyze the influence of various factors on the social integration of migrant workers, this paper sets the following equation:

$$
\begin{aligned}
S I_{i} & =\beta_{0}+\beta_{1} \text { age }_{i}+\beta_{2} \text { gen }_{i}+\beta_{3} e d u_{i}+\beta_{4} \text { tim }_{i}+\beta_{5} \text { inc }_{i}+\beta_{6} \text { con }_{i} \\
& +\beta_{7} \text { lei }_{i}+\beta_{8} \text { mar }_{i}+\beta_{9} \text { ins }_{i}+\beta_{10} s r_{i}+\varepsilon_{i}
\end{aligned}
$$

Where dependent variable $\mathrm{SI}_{\mathbf{i}}$ denotes the social integration of migrant workers. $l e i_{i}$ is the variable of leisure activity participation, which is dummy equal to 1 if yes, otherwise 0 .

In order to control the heteroscedasticity, we conduct testing Breusch-Pagan. The reject of the null hypothesis suggests heteroscedasticity. Using robust least square estimation of estimation results to control the heteroscedasticity. Table 2 shows the estimated results.

\begin{tabular}{|c|c|c|c|c|c|c|}
\hline & $\begin{array}{c}1 \\
\text { Social } \\
\text { integration }\end{array}$ & $\begin{array}{c}2 \\
\text { Social } \\
\text { distance }\end{array}$ & $\begin{array}{c}3 \\
\text { Cultural } \\
\text { integration }\end{array}$ & $\begin{array}{c}4 \\
\text { Psychological } \\
\text { integration }\end{array}$ & $\begin{array}{c}5 \\
\text { Social } \\
\text { interaction }\end{array}$ & $\begin{array}{c}6 \\
\text { Settlement }\end{array}$ \\
\hline age & $\begin{array}{c}-0.048 * * * \\
(-0.017)\end{array}$ & $\begin{array}{l}-0.071^{*} \\
(0.036)\end{array}$ & $\begin{array}{c}-0.132 * * * \\
(0.027)\end{array}$ & $\begin{array}{l}-0.051 * \\
(-0.034)\end{array}$ & $\begin{array}{c}-0.011 \\
(-0.022)\end{array}$ & $\begin{array}{c}0.02 * \\
(0.034)\end{array}$ \\
\hline sex & $\begin{array}{c}0.063 * \\
(0.034)\end{array}$ & $\begin{array}{c}0.353 * * * \\
(0.072)\end{array}$ & $\begin{array}{c}0.018 \\
(0.055)\end{array}$ & $\begin{array}{l}-0.036 * \\
(-0.069)\end{array}$ & $\begin{array}{c}0.13 * * * \\
(0.045)\end{array}$ & $\begin{array}{c}-0.159 \\
(-0.069)\end{array}$ \\
\hline education & $\begin{array}{c}0.09^{*} \\
(0.018)\end{array}$ & $\begin{array}{l}0.049 * \\
(0.039)\end{array}$ & $\begin{array}{l}0.005 * \\
(0.029)\end{array}$ & $\begin{array}{c}0.075 * * \\
(0.037)\end{array}$ & $\begin{array}{l}0.043^{*} \\
(0.024)\end{array}$ & $\begin{array}{l}0.057 * \\
(0.037)\end{array}$ \\
\hline duration & $\begin{array}{c}0.003 \\
(0.015)\end{array}$ & $\begin{array}{c}-0.08 \\
(0.031)\end{array}$ & $\begin{array}{c}-0.054 \\
(-0.024)\end{array}$ & $\begin{array}{l}0.082 \\
(0.03)\end{array}$ & $\begin{array}{c}0.011 \\
(0.019)\end{array}$ & $\begin{array}{c}0.058^{*} \\
(0.03)\end{array}$ \\
\hline martial & $\begin{array}{c}0.086 * * \\
(0.042)\end{array}$ & $\begin{array}{c}0.036 * * \\
(0.088)\end{array}$ & $\begin{array}{c}0.175 * * * \\
(0.066)\end{array}$ & $\begin{array}{l}0.21 * * \\
(0.084)\end{array}$ & $\begin{array}{c}0.014 * * \\
(0.054)\end{array}$ & $\begin{array}{c}0.071 * * \\
(0.084)\end{array}$ \\
\hline income & $\begin{array}{c}0.26 * * * \\
(0.017)\end{array}$ & $\begin{array}{l}0.144 * \\
(0.037)\end{array}$ & $\begin{array}{c}0.02 * \\
(0.028)\end{array}$ & $\begin{array}{l}0.033^{*} \\
(0.035)\end{array}$ & $\begin{array}{l}0.035^{*} \\
(0.023)\end{array}$ & $\begin{array}{c}0.11 * \\
(0.035)\end{array}$ \\
\hline consumption & $\begin{array}{c}0.024 * * \\
(0.012)\end{array}$ & $\begin{array}{l}0.026 * \\
(0.026)\end{array}$ & $\begin{array}{c}0.016^{*} \\
(0.02)\end{array}$ & $\begin{array}{l}0.045^{*} \\
(0.025)\end{array}$ & $\begin{array}{c}0.054 * * * \\
(0.016)\end{array}$ & $\begin{array}{c}-0.018 \\
(-0.025)\end{array}$ \\
\hline leisure & $\begin{array}{l}0.08 * * \\
(0.031)\end{array}$ & $\begin{array}{c}0.117 * * \\
(0.066)\end{array}$ & $\begin{array}{l}0.042 \\
(0.05)\end{array}$ & $\begin{array}{c}0.023 \\
(0.064)\end{array}$ & $\begin{array}{c}0.100 * * \\
(0.041)\end{array}$ & $\begin{array}{c}0.121 \\
(0.063)\end{array}$ \\
\hline institution & $\begin{array}{c}0.175 * * * \\
(0.022)\end{array}$ & $\begin{array}{l}0.154 * \\
(0.047)\end{array}$ & $\begin{array}{c}0.11 * * * \\
(0.036)\end{array}$ & $\begin{array}{l}0.069 * \\
(0.045)\end{array}$ & $\begin{array}{c}0.068 * * \\
(0.029)\end{array}$ & $\begin{array}{l}0.072 * \\
(0.045)\end{array}$ \\
\hline interaction & $\begin{array}{c}0.145 * * * \\
(0.014)\end{array}$ & $\begin{array}{c}0.082 * * * \\
(0.029)\end{array}$ & $\begin{array}{c}0.049 * * \\
(0.022)\end{array}$ & $\begin{array}{c}0.165^{* * * *} \\
(0.028)\end{array}$ & & $\begin{array}{c}0.183^{* * * *} \\
(0.028)\end{array}$ \\
\hline constant & $\begin{array}{c}2.434 * * * \\
(0.126)\end{array}$ & $\begin{array}{c}3.156 * * * \\
(0.266)\end{array}$ & $\begin{array}{c}3.291 * * * \\
(0.201)\end{array}$ & $\begin{array}{c}1.721 * * * \\
(0.254)\end{array}$ & $\begin{array}{c}1.546^{* * *} \\
(0.165)\end{array}$ & $\begin{array}{c}2.471 * * * \\
(0.254)\end{array}$ \\
\hline Observations & 798 & 801 & 799 & 801 & 801 & 800 \\
\hline R-squared & 0.555 & 0.574 & 0.552 & 0.588 & 0.403 & 0.487 \\
\hline
\end{tabular}

Table 2. Regression results

Note: standard errors are included in the parentheses. $* * * \mathrm{p}<0.01, * * \mathrm{p}<0.05, * \mathrm{p}<0.1 /$

As we can see from this table, the coefficients of leisure participation are significantly positive in model 1, which suggests that leisure participation of migrant workers has a positive effect on the social integration. the possible explanation is that the working life of migrant workers in cities is boring, and participation in leisure activities can enrich their amateur cultural life, increase social capital, and improve the happiness of life in the city, which is helpful to promote the degree of social integration of migrant workers. Second, we find that the leisure participation has a significant and strong positive effect on social distance and social interaction (coefficient of 0.117 and 0.1 , respectively), which indicates that participation in leisure activities can shorten the distance with the 
local society, increase in workers' social interaction. However, we find that the estimated coefficient of leisure activity participation in the overall social integration is relatively small, indicating that the effect of the participation of leisure activities on the social integration of migrant workers is not strong.

\section{Conclusion}

This paper analyzes the situation and impact of participation of leisure activities on social integration of migrant workers from group heterogeneity perspective. The study indicates that participation of leisure activities can promote social integration of migrant workers significantly. Moreover, Social-type and arty-type leisure activities can aggrandize social integration of migrant workers, the effect of sporty-type leisure activities isn't notable, but, recreational leisure activities will undermine social integration.

\section{References}

[1]. Park R E, Burgess E W. Introduction to the science of sociology. 1921. Reprint[M]. Chicago: The University of Chicago Press, 1969.

[2]. Berger B G, Owen D R. Stress reduction and mood enhancement in four exercise modes: Swimming, body conditioning, hatha yoga and fencing $[\mathrm{J}]$. Research Quarterly for Exercise and Sport,1988, 59 (2): 148- 159. 